\title{
Een irenische dialoog met Wim Weren over geweld in Johannes 7:53-8:11
}

\author{
Joseph Verheyden ${ }^{1}$ \\ Katholieke Universiteit Leuven \\ België
}

\begin{abstract}
An irenic dialogue with Wim Weren about violence in John 7:53-8:11

This essay engages in a dialogue with Wim Weren's contribution in this volume. It first discusses some hermeneutical perspectives on violence in the pericope on the adulteress woman in John 7:53-8:11. It then discusses the use of Deuteronomy in this passage against the background of Jesus' radical new perspective on violence.
\end{abstract}

\section{INTRODUCTIE}

Met dit korte antwoord heb ik geenszins de bedoeling in te gaan op alle aspecten van de problematiek die professor Wim Weren op tafel heeft gebracht in zijn gedetailleerde studie van deze bijna iconische tekst uit het vierde evangelie. Ik zal slechts een paar punten aanraken, en misschien hier of daar een wenkbrauw doen rijzen.

Het artikel van Weren bestaat uit een inleiding en drie paragrafen. In de Inleiding licht de auteur de keuze van het onderwerp toe, en hij doet dit op een wel zeer dramatische wijze. Het hoeft geen betoog dat wij allen de plicht hebben om dergelijke praktijken als daar vermeld worden aan de kaak te stellen.

Maar wij moeten er ons tegelijk voor hoeden de zaken niet te sterk te vereenvoudigen en al te snel te gaan spreken in termen van "barbaars" versus "beschaafd." De zaken liggen namelijk moeilijker, vrees ik, zoals ik

\footnotetext{
${ }^{1}$ Prof dr Jos Verheyden (Faculteit Godgeleerdheid, Katholieke Universiteit Leuven, België) en prof dr Wim J C Weren (Departement Religiewetenschappen en Theologie van de Faculteit Geesteswetenschappen, Universiteit van Tilburg, Nederland) zijn als gastonderzoekers betrokken bij het project "Hermeneutiek" van prof dr Andries G van Aarde in de Afdeling Nieuw Testamentische Wetenschap van de Faculteit Theologie, Universiteit van Pretoria.
} 
lang geleden eens mocht ondervinden in een gesprek met een Iranese student, een fervent aanhanger van de Ayatollah Khomeini in de beginjaren van het regime. Toen ik de man, die opmerkelijk goed Frans sprak, er op wees dat wij toch de grootste moeite hebben met de wel zeer wrede manier waarop in Iran en andere landen bepaalde daden werden bestraft (er waren net een tiental mensen opgeknoopt wegens drugshandel) en hem vroeg of hij niet vreesde dat zoiets bijzonder slecht overkomt in het Westen, was zijn antwoord even eenvoudig als verrassend. De man repliceerde als volgt (ik citeer min of meer letterlijk uit het geheugen):

Wij vinden dit soort bestraffing even wreed als jullie westerlingen,
wij beleven daar heus geen plezier aan en het schokt ons
evenzeer, maar wij passen ze toch toe omdat wij de daad waarvoor
de beschuldigden veroordeeld zijn even wreedaardig vinden. Dat is
jullie probleem: jullie vinden ook dat bepaalde dingen absoluut
barbaars zijn, maar jullie zijn niet consequent wanneer het er dan
op aan komt de daders daarvoor ter verantwoording te roepen. Met
andere woorden, wij maken van ons hart een steen omdat het nu
eenmaal moet. Jullie daarentegen laten het slachtoffer in de kou
staan.

Ik wist toen niet goed hoe ik daarop moest antwoorden, en nu eigenlijk nog niet vrees ik, tenzij ik Jezus en het Nieuwe Testament ter sprake wou brengen.

Na de Inleiding behandelt Weren in zijn bijdrage eerst de regels in Deuteronomium 22:13-29 met betrekking tot seksueel verkeer. Daarna bespreekt hij de houding van Jezus tegenover het gebruik van de doodstraf ter bestraffing van overspel. Hij gaat in op enkele van de notoire tekstkritische en literair-historische problemen die verbonden zijn met de tekst van Joh 7:53-8:11, en gaat na hoe het voorschrift uit Deuteronomium 22:22 in Johannes 7:53-8:11 geïnterpreteerd wordt, om vervolgens het perspectief uit te breiden naar andere oudtestamentische teksten die mogelijk een rol hebben gespeeld, en dan te besluiten met een meer methodologische vraag betreffende de relevantie van dergelijke teksten voor onze tijd.

\section{HET GEBRUIK VAN DEUTERONOMIUM IN JOHANNES}

\section{7:53-8:11}

Veel aan deze tekst is inderdaad onduidelijk en problematisch, zoals Weren terecht opmerkt. De manier waarop kopiisten met de tekst zijn omgesprongen of gezeuld hebben zegt veel over de moeilijkheden die de passage oproept. Over de oorsprong en vroegste overlevering weten wij omzeggens niets; hoe 
de tekst in het evangelie van Johannes, en nadien ook in Lucas, terechtkwam is al even mysterieus, en wat de bedoeling van de tekst betreft kunnen wij ons vermeien in een hele reeks verklaringen en gissingen. Twee dingen zijn echter duidelijk. Enerzijds is de tekst duidelijk geïnspireerd op Deuteronomium 22:13-29 - de vermelding van de Wet van Mozes en meer bepaald de steniging verwijst zelfs min of meer uitdrukkelijk naar die passage - maar merkwaardig genoeg lijkt de auteur op geen enkele wijze geïnteresseerd te zijn in de legale context of in de juridische kwesties en procedures die daar ter sprake komen. Anderzijds is de passage ook duidelijk gekleurd door zinsneden en motieven die elders in Joh en in andere evangelies voorkomen en die het secundaire karakter van Johannes 7:53-8:11 aantonen. De twee kenmerken zijn echter ontegensprekelijk met elkaar verbonden, en wat meer is, wellicht levert het tweede punt (ten dele) de verklaring voor het eerste en voor de interpretatie van de passage.

In zoverre mijn vorige bemerking correct is zou men (misschien met enige overdrijving) kunnen zeggen dat de hele analyse van Deuteronomium 22:13-29, met de grote aandacht voor casuïstiek, voor de te volgen procedures, en voor het soort van bestraffing dat dient te worden uitgesproken, eigenlijk enigszins overbodig is. En toch is de analyse niet zonder nut omdat ze duidelijk maakt, als e contrario, dat de auteur van Johannes 7:53-8:11 op geen enkele manier in die problematiek geïnteresseerd is. Zijn Jezus stelt zich geen vragen bij de juridische kant van de zaak. Hij aanvaardt zonder meer dat de Farizeeërs de waarheid spreken over de vrouw, zoals ten andere ook blijkt uit zijn antwoord aan haar in vers 11. Hij vraagt ook niet naar procedurekwesties, of er getuigen waren, of er een formeel proces is geweest, zelfs niet waar of wie de partner van de vrouw is. Jezus procedeert op een heel andere basis, een basis die niet onbekend is in het Oude Testament, met name de moraliteit van de getuigen, maar hij herinterpreteert dat thema hier als een vraag naar de moraliteit van de aanklagers en rechters (en mogelijk ook uitvoerders van de straf), en bovendien verwoordt hij het ook in meer radicale termen wanneer hij vraagt of zij zelf zonder zonden zijn om dan zwijgend op de grond te gaan schrijven.

Johannes 7:53-8:11 is het verhaal van een overtreding 'op heterdaad', maar in tegenstelling tot Deuteronomium 22 lijkt het hier om een concrete persoon te gaan. Dergelijke concretisering is niet onbekend in de evangelies (de rijke jongeman in Marcus 10 stelt zichzelf als voorbeeld), maar in Johannes krijgt de vrouw helemaal geen individualiteit en wordt zij in feite gedegradeerd tot een pure "casus" totdat Jezus haar op het einde zelf aanspreekt, maar ook dan krijgt zij geen eigen stem. Het gaat dus blijkbaar nooit echt om haar; de antagonisten zijn Jezus en zijn opponenten. Dit is het 
verhaal van een provocatie - de parenthese in vers 6 zegt het met zoveel woorden - die Jezus eerst onbeantwoord laat - hij gaat op de grond zitten schrijven! - en dan countert op een onverwacht radicale manier die de opponenten meteen het zwijgen oplegt, waarna Jezus doorgaat met schrijven, een activiteit die veel inkt heeft doen vloeien en die ik zou willen verstaan misschien enigszins gedurfd - als een originele uiting van hoe Jezus afstand neemt van zijn gesprekspartners en van hun poging om hem in de val te lokken en op te zetten tegen de Wet. In antwoord op die poging krabbelt Jezus wat op de grond, quasi ongeïnteresseerd in hun vraag en hun bijbedoelingen. Kortom, het gaat in dit verhaal in wezen niet om wat de Wet zegt, maar om het woord van Jezus aan de Farizeeërs-aanklagers-beulen, en nadien ook om wat hij tot de vrouw te zeggen heeft.

\section{EEN ALLESOMVATTENDE VOORWAARDE}

Maar wat dan met de vraag van de Farizeeërs? Heeft Jezus met zijn antwoord werkelijk de Wet van Mozes onaangetast gelaten zoals Weren beweert? De Wet lijkt toch minstens de facto buiten werking gesteld, aangezien de voorwaarde die Jezus formuleert uitvoering van de straf in feite onmogelijk maakt, want wie kan inderdaad zeggen dat hij werkelijk zonder zonden is, dat hij werkelijk in alle opzichten altijd alle verordeningen van de Torah onderhouden heeft. Want dat is uiteraard wat bedoeld is: het gaat niet om de vraag of de aanklagers zelf al dan niet ooit overspel of echtbreuk hebben gepleegd; er wordt daarentegen een allesomvattende voorwaarde geformuleerd.

Of dienen wij misschien nog een stap verder te gaan en te stellen dat Jezus het gebod in de Torah over bestraffing van echtbreuk en overspel zelfs de iure opheft door een heel ander criterium te laten spelen. Ik neig tot die laatste opvatting. In 8,10-11 verklaart Jezus expliciet dat de vrouw gezondigd heeft, maar toch veroordeelt zelfs hij, die zonder zonden is, haar niet. Jezus heeft de controverse waar de Farizeeërs-aanklagers met beroep op de Wet van Mozes op aansturen (zie 8:6 en vgl Matt 22:15) aangegrepen om er een ander, hoger principe tegenover te stellen, een principe dat op een meer formele manier verwoord is in bijvoorbeeld Mattheus 7:1 (par. Luc 6:37): oordeel niet en je zal niet geoordeeld worden. Dit brengt de opponenten tot zwijgen. Opnieuw druipen zij af, zoals in die andere prototypische controverse in Mattheus 22:15-22 over het betalen van belasting. Daaraan knoopt Jezus een even indrukwekkend principe, met name dat vergeving altijd primeert, zelfs over een daad die volgens de traditie én de Wet met de dood bestraft dient te worden. Dit tweede principe wordt hier weliswaar niet expliciet zo geformuleerd (Jezus gebruikt het woord "vergeving" niet), maar het is evident 
bedoeld wanneer hij de zondige vrouw eenvoudig wegstuurt met de woorden "ook ik veroordeel u niet, ga en zondig niet meer" (Joh 8:11), zoals hij ook had gezegd tot de lamme in Johannes 5:14, in een andere hoogst controversiële uiteenzetting met zijn opponenten, nu over het onderhouden van de sabbat.

\section{AANKLACHT TEGEN DE HEERSENDE MORAAL}

Tenslotte, de antieke cultuur en leefwereld is in menig opzicht ongetwijfeld bevreemdend voor de moderne lezer. Dat uit zich onder andere ook in de omgang met geweld en seks zoals Weren illustreert. De perikoop van de overspelige vrouw is belangrijk, want dit verhaal is meer dan een "aanzet" tot het decriminaliseren van overspel of echtbreuk. Het laat Jezus radicaal komaf maken met de oude kijk op de dingen. Het gaat in dit verhaal naar mijn mening dan ook om veel meer dan "eer" of schaamtegevoel. Het is een regelrechte aanklacht tegen de heersende moraal én tegen de bestaande rechtspraxis, waarbij voor een radicaal andere oplossing wordt gekozen en de lezer wordt opgeroepen een totaal andere ingesteldheid te verwerven. Voor geweld is daar onder geen beding nog een plaats, en de reden daarvoor ligt bij onszelf: de mens kan een ander niet veroordelen en bestraffen, zelfs niet volgens de principes van Gods Wet, aldus Jezus.

De moordende consistentie van het bestel waar Jezus tegen in opstand komt wordt door hem weggeschreven in het zand en weggeblazen door zijn woord. Wanneer dit verhaal gelezen wordt in het geheel van het evangelie moet men echter vaststellen dat het de tegenstanders alleen maar heeft aangemoedigd. Twee dreigen er gestenigd te worden in het evangelie van Johannes - Jezus in Johannes 8:59, en opnieuw in Johannes 10:32 en $11: 8$, en een anonieme vrouw in Johannes 7:53-8:11. Geen van beiden wordt tenslotte ook echt gestenigd. Maar een van hen sterft wel een gewelddadige dood. Toch is dat niet het laatste woord. Jezus heeft het gebruik van geweld bestreden en, voor wie in hem gelooft, ook overwonnen. 